\title{
Sealworm Pseudoterranova decipiens s.S. infection of European smelt Osmerus eperlanus in German coastal waters: ecological implications
}

\author{
Thomas Kuhn $^{1}$, Tim Benninghoff ${ }^{2}$, Horst Karl ${ }^{3}$, Thomas Landry ${ }^{4}$, Sven Klimpel ${ }^{1, *}$ \\ ${ }^{1}$ Biodiversity and Climate Research Centre (BiK-F), Medical Biodiversity and Parasitology, \\ Senckenberg Gesellschaft für Naturforschung (SGN), Goethe-University (GO), Institute for Ecology, \\ Evolution and Diversity, Senckenberganlage 25, 60325 Frankfurt/Main, Germany \\ ${ }^{2}$ German Diabetes Center (DDZ), Leipniz Center for Diabetes Research at the Heinrich-Heine-University Düsseldorf, \\ Institute of Clinical Biochemistry and Pathobiochemistry, Auf'm Hennekamp 65, 40225 Düsseldorf, Germany \\ ${ }^{3}$ Department of Safety and Quality of Milk and Fish Products, Federal Research Institute for Nutrition and Food, \\ Max Rubner-Institut, Palmaille 9, 22767 Hamburg, Germany \\ ${ }^{4}$ Department of Fisheries and Oceans, Gulf Region, PO Box 5030, Moncton, New Brunswick E1C 9B6, Canada
}

\begin{abstract}
European smelt Osmerus eperlanus $(\mathrm{n}=501)$ from the German Wadden Sea (North Sea) near the city of Cuxhaven were examined for their infestation with parasitic anisakid nematodes, especially with sealworms of the genus Pseudoterranova. The distribution of third-stage larvae (L3) in the musculature and viscera of the fish was analyzed. In total, we isolated 543 L3 from the hosts' body cavity and musculature. A subsample of 105 larvae were identified as the (sibling) species $P$. decipiens s.s. using direct sequencing of the highly variable ribosomal ITS1-5.8S-ITS2 genetic marker. The mean abundance was 1.1, the mean intensity was 2.3 P. decipiens s.s. and the prevalence was $47.3 \%$. Total length and total weight, but not Fulton's condition factor $(K)$, were significantly different in infected compared to uninfected smelt. No correlation was found between the total length of infected fish and the intensity of anisakid nematodes. The vast majority of $P$. decipiens s.s. was found in the musculature of the smelt. More than half $(55.7 \%)$ of all nematodes were located in the 3 parts of the epaxial musculature, whereas 18.4 and $26.0 \%$ were found in the hypaxial musculature and the compartments of the tail muscles, respectively.
\end{abstract}

KEY WORDS: North Sea $\cdot$ Wadden Sea $\cdot$ Anisakid nematodes $\cdot$ Species complex $\cdot$ Phoca vitulina Zoonosis

\section{INTRODUCTION}

The Wadden Sea is a shallow intertidal marine ecosystem in the North Sea between the coasts of The Netherlands and Denmark and is the largest temperate zone tidal flat system in the world (Reise et al. 2010). It covers an area of about $14700 \mathrm{~km}^{2}$ and is characterized by continuous flooding and drying events and an enormous primary and secondary production (Wolff et al. 2010). It is also an essential nurs- ery area for commercially important fish species and a foraging and resting habitat for seals and wading birds (e.g. Reise et al. 2010, Wolff et al. 2010). European smelt Osmerus eperlanus, L. 1758 are common bentho-pelagic predatory schooling fish with a mean length of $16.5 \mathrm{~cm}$. Smelt are widely distributed in shallow waters of the Northeast Atlantic and are highly abundant in the North and Baltic Seas (Kovpak et al. 2011, Froese \& Pauly 2012). They are predatory, usually feeding on shrimps and small 
crustaceans, and larger individuals also prey upon small fishes (Froese \& Pauly 2012). Smelt are anadromous migratory fish that group together during the winter months along the estuarine zones for reproduction and move up from February to May into rivers to spawn (Karl 2006, Froese \& Pauly 2012). During these months they are caught, especially along the Elbe estuary in Germany, on a large scale and served headed and fried, or smoked as a traditional regional specialty in many German restaurants.

It is thought that Osmerus eperlanus is the most important fish intermediate/transport host of the sealworm Pseudoterranova decipiens s.l. in the Elbe estuary and probably also in adjacent coastal waters of the Wadden Sea (Rohlwing et al. 1998, Karl 2006). These ascaridoid parasitic nematodes belong to the family Anisakidae, and are abundant in the flesh of many marine and euryhaline fish species (e.g. McClelland et al. 1983, Mattiucci \& Nascetti 2008). Beside the commercial losses for the seafood processing industry, caused by the presence of these worms in the fillets of many important food fishes (e.g. Gadus morhua, Pollachius virens, Hippoglossus sp.), sealworms are potentially capable of causing anisakiasis-like symptoms in humans (e.g. abdominal pain, nausea, fever) when consumed in lightly cooked or raw fish products (pseudoterranovosis; e.g. Rae 1963, Margolis 1977, Yu et al. 2001, McClelland 2002, Audicana \& Kennedy 2008).

In contrast to the more pelagically orientated life cycle of the closely related Anisakis spp., the heteroxenous life cycle pattern of Pseudoterranova spp. seems to be associated more with benthic and epibenthic habitats (Køie et al. 1995, McClelland 2002, Klimpel \& Palm 2011). Pinnipeds of the families Otariidae and Phocidae have been reported to act as final hosts, whereas benthic micro- and macro invertebrates as well as benthic and demersal teleost fish species serve as (obligatory) intermediate/transport hosts (Anderson 2000, McClelland 2002, Mattiucci \& Nascetti 2008). In the North and Wadden Seas, grey seals Halichoerus grypus and common or harbor seals Phoca vitulina act as main definitive hosts in the life cycle of the parasite. Recent surveys on the common seal population in the Wadden Sea have suggested a 'solid increase' in their population (TSEG 2011). The eggs are shed with the feces of the final host and presumably descend to the seabed, where they develop and adhere to the substrate by their caudal ends (McClelland 2002, Klimpel \& Palm 2011). The newly hatched, ensheathed larvae are ingested by small benthic crustaceans (e.g. harpacticoid and cyclopoid copepods, amphipods, isopods, gammarids), whereupon they penetrate the host's hemocoel and begin to grow into third-stage larvae (L3). Once ingested by fish, the L3 usually establish themselves in the internal organs or settle in the musculature, where they continue growing in length (McClelland 2002, 2005, Karl 2006, Klimpel \& Palm 2011). Further intermediate, transport, or paratenic hosts can be infected (e.g. piscivorous fish) before the parasite reaches the adult stage after ingestion by seals.

Due to the very limited eligible morphological characters, species identification of larval nematodes from marine vertebrates is difficult. Polymerase chain reaction based analyses of highly variable markers such as the nuclear ribosomal ITS1-5.8SITS2, or the mitochondrial cytochrome $c$ oxidase subunit 2 have proven to be powerful tools for separating even very closely related (sibling) species that lack morphological differences (e.g. Zhu et al. 2000, Nadler et al. 2005, Mattiucci et al. 2007, Quiazon et al. 2009). These molecular analyses provide evidence that Pseudoterranova decipiens represents a species complex comprising 6 different species ( $P$. decipiens S.s., P. krabbei, P. bulbosa, P. azarasi, P. decipiens E, $P$. cattani) with different zoogeographical distributions and host ecologies (e.g. Zhu et al. 2002, Mattiucci \& Nascetti 2008, Klimpel \& Palm 2011). In North Atlantic waters, the closely related P. decipiens s.s. and $P$. krabbei are known to infect harbor seals and grey seals and therefore potentially infest the intermediate host Osmerus eperlanus (Lick 1991, Paggi et al. 1991, 2000).

Sealworm infections of commercially valuable fish species are a cost-intensive problem for the fish and seafood processing industry (McClelland 2002). The occurrence of nematodes in the European smelt has been extensively investigated (e.g. Möller \& Klatt 1990, Obiekezie et al. 1992, Karl 2006). However, comparatively few current studies have been conducted regarding both the number and the location of larvae in different areas of the edible muscle parts and the molecular analyses of the parasites. In a large-scale study, Möller \& Klatt (1990) sampled smelt from different year groups and investigated the distribution of larvae only in 3 body parts (dorsal muscle, belly flaps, and tail) but omitted the occurrence of nematodes in the viscera of the fish. Karl (2006) examined a total of 300 ready-to-cook Osmerus eperlanus by using the 'press/UV-method.' That author quantified the nematodes in the edible parts and investigated possible post mortem migration events of larvae out of the freshly caught fish. The aim of the present study was to assess the para- 
site burden in the intestines and musculature of the European smelt $O$. eperlanus with zoonotic anisakid nematodes of the genus Pseudoterranova. Quantitative parasitological calculations were performed and a subsample of nematodes was identified to species level using the ribosomal ITS1-5.8S-ITS2 genetic marker. The distribution of L3 nematodes in the musculature and viscera was analyzed, and the host-parasite relationship between $O$. eperlanus and Pseudoterranova is discussed in the context of the ecosystem.

\section{MATERIALS AND METHODS}

\section{Parasitological examination}

We dissected a total of 501 Osmerus eperlanus to assess the infection levels with Pseudoterranova larvae in the viscera and musculature. The samples were obtained fresh from local fishermen from the Elbe estuary in the North Sea near Cuxhaven, Germany, in March 2010. They were transported on ice to the Institute of Zoomorphology, Cell Biology, and Parasitology in Düsseldorf, where they were frozen for subsequent examination. Total weight (TW) was measured to the nearest $0.1 \mathrm{~g}$, and total length (TL) was measured to the nearest millimeter. The body cavity was opened and the internal organs were removed. Liver, stomach, pyloric caeca, intestine, and gonads were examined for anisakid parasites using a stereomicroscope. Musculature was divided into 8 different parts that were screened for nema- todes using a candling table: epaxial muscle (cranial, postcranial, caudal), hypaxial muscle (cranial, postcranial, caudal), and tail muscle (subterminal, terminal; Fig. 1). The locations of parasites in the sections were recorded. All specimens were washed in saline solution $(0.9 \%)$ and preserved in absolute ethanol for molecular identification.

\section{Molecular analysis}

Genetic species identification was performed on 105 anisakid larvae. Genomic DNA was extracted and purified from each larva using an AcroPrep PALL 96-well plate $(1 \mathrm{ml} ; 1 \mu \mathrm{m})$ glass fiber plate according to the instructions provided by Ivanova et al. (2006). The rDNA region comprising the ITS1-5.8SITS2, and flanking sequences (= ITS+) was amplified using the primers NC2 $\left(5^{\prime}\right.$-TTA GTT TCT TTT CCT CCG CT-3') and TK1 (5'-GGC AAA AGT CGT AAC AAG GT-3'; Zhu et al. 2000, 2002, Kuhn et al. 2011). PCR-reactions $(25 \mu \mathrm{l})$ included $12.5 \mu \mathrm{l}$ Master-Mix (Peqlab Biotechnology) containing dNTP, $\mathrm{MgCl}_{2}$, buffer, and Taq-polymerase, $1.5 \mu \mathrm{l}$ of each primer

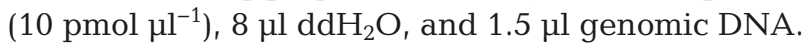
Each PCR reaction was performed in a thermocycler (Peqlab) under the following conditions: after an initial denaturation at $95^{\circ} \mathrm{C}$ for $1 \mathrm{~min}, 40$ cycles at $94^{\circ} \mathrm{C}$ for $45 \mathrm{~s}$ (denaturation), $55^{\circ} \mathrm{C}$ for $45 \mathrm{~s}$ (annealing), and $72^{\circ} \mathrm{C}$ for $45 \mathrm{~s}$ (extension), followed by a final extension at $72^{\circ} \mathrm{C}$ for $10 \mathrm{~min}$. Samples without DNA were included in each PCR run. PCR products were examined on $1 \%$ agarose gels. A 100 bp ladder

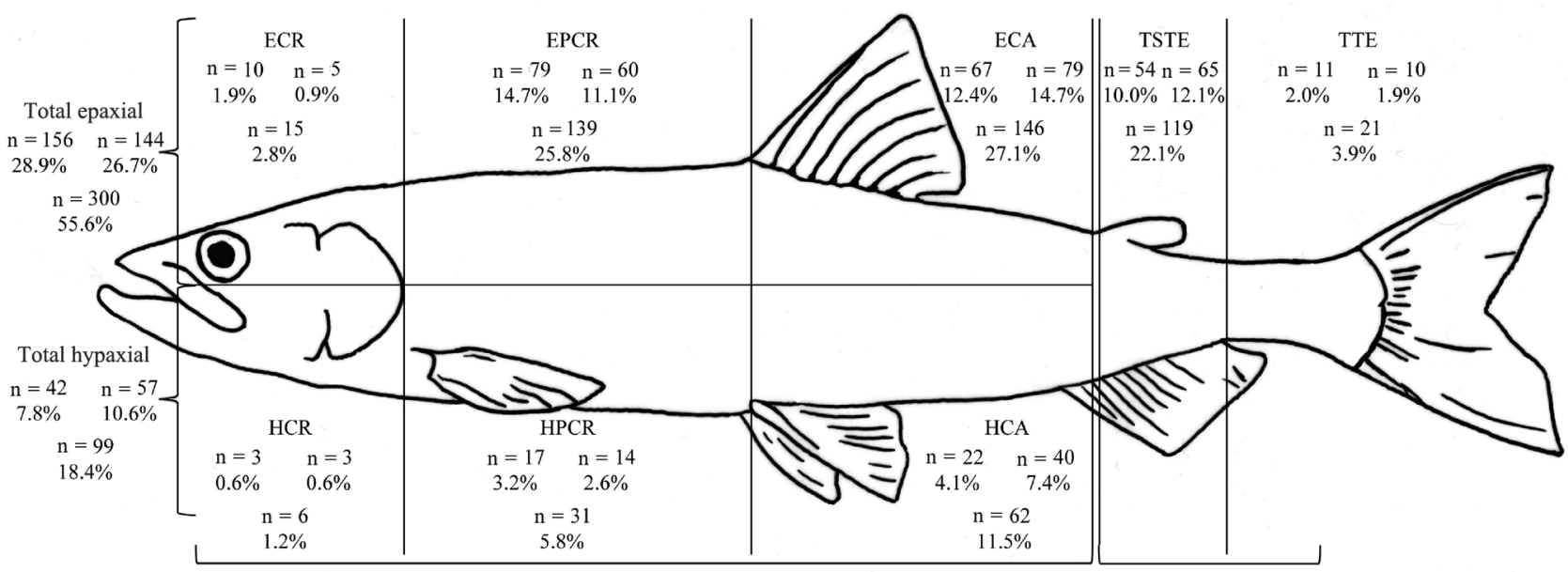

Fig. 1. Osmerus eperlanus infected with Pseudoterranova decipiens. Infection rates (absolute and relative no. of parasites found) and distribution of nematode larvae in the muscle parts of smelt. Rates are given for left and right body side (upper values), and as totals for both sides (lower values). ECR: epaxial cranial, EPCR: epaxial postcranial, ECA: epaxial caudal, TSTE: tail subterminal, TTE: tail terminal, HCR: hypaxial cranial, HPCR: hypaxial postcranial, HCA: hypaxial caudal 
marker (peqGOLD) was used to estimate the size of the PCR products. Both spacers and the 5.8S gene from each PCR product were sequenced by the Seqlab Sequencing Laboratory (Göttingen, Germany), using the primer TK1 (5'-GGC AAA AGT CGT AAC AAG GT-3'). For species identification, the obtained sequences were compared to GenBank data using the BLASTn algorithm (Altschul et al. 1990).

\section{Data analysis}

The terminology for ecological and parasitological parameters follows Ricker (1975) and Bush et al. (1997). Statistical analyses were performed using Graphpad Prism software version 5.01. Total length (TL), total weight (TW), and Fulton's condition factor $(K)$ were calculated and tested for normal distribution (D'Agostino \& Pearson omnibus K2 normality test). Mann-Whitney unpaired, 2-tailed $U$-tests were performed to compare TL and TW, while an unpaired 2-tailed $t$-test was used to compare $\mathrm{K}$ of uninfected and infected (male and female) Osmerus eperlanus (Table 1). Spearman's rank test was used to analyze the relationship between parasite intensity and TL of the hosts.

\section{RESULTS AND DISCUSSION}

With a total of 426 male and 75 female smelt, there was a clear imbalance in favor of male individuals (85.0\%; Table 1). TL and TW were not normally distributed (D'Agostino \& Pearson normality test; p < $0.0001)$ and ranged from 9.9 to $22.5 \mathrm{~cm}$ (mean = $17.2 \mathrm{~cm}$ ) and 4.4 to $91.6 \mathrm{~g}$ (mean = $30.5 \mathrm{~g})$. Whilst females $($ mean $=17.9 \mathrm{~cm}$ ) were significantly larger than males $($ mean $=17.1 \mathrm{~cm}$; Mann-Whitney unpaired, 2-tailed $U$-test; $\mathrm{p}<0.0127$ ), no significant differences in TW were observed. The results are similar to those reported by Karl (2006) and Möller \& Klatt (1990) and represent on average the common length and weight of commercially offered Osmerus eperlanus.

We found 237 infected smelt, while 264 were uninfected. In total, 543 (539 in the musculature, 4 in the intestines) anisakid nematode specimens were recovered from the body cavities, intestines, and musculature of the smelt, with a total prevalence of $47.3 \%$, a mean abundance of 1.1 , and a mean intensity of 2.3 (Table 1). While mean abundance (1.1), intensity (1 to 12), and mean intensity (2.4) were higher among males than females, the prevalence of infection was higher (by 8.7\%) in females. These data are very similar to those from January 2005 presented by Karl (2006), who found a prevalence of $44 \%$ and a mean abundance and mean intensity of 1.2 and 2.7, respectively. In contrast, the prevalences recorded in March 2005 (29\%) and 2006 (36\%) during the same study were much lower (Karl 2006). The smelt analyzed in the present study, however, were collected in March 2010 and when compared to the prevalence found by Karl (2006) in March 2005 and March 2006, the value has increased at a rate of $3.42 \%$ per year (linear regression analysis; $\mathrm{R}^{2}=0.96$ ).

TL and TW were significantly higher in infected compared to uninfected fish $(\mathrm{p}<0.0028)$. Separated by gender, there was a significant difference in length and weight for infected males ( $p<0.0019$; $p<$ 0.0060 ), but not for infected females ( $p<0.9448$; $0.6664)$. The value of Fulton's $K$ ranged from 0.4 to 0.7 (mean $=0.5$ ) for both uninfected and infected fish; there were no differences between infected and uninfected males, nor between male and female smelt (Table 1).

Table 1. Osmerus eperlanus infected with Pseudoterranova decipiens. Fish biometric data and infection parameters (sample, infected, uninfected) separated by gender. Median and range (in parentheses) are provided for total length (TL) and total weight (TW). P: prevalence; mA: mean abundance; I: intensity; mI: mean intensity. Arithmetic mean and range are provided for Fulton's K. CI (95\%) is given for mA and mI. M: male, F: female

\begin{tabular}{|c|c|c|c|c|c|c|c|c|c|}
\hline \multirow[b]{2}{*}{ Sex } & \multirow[b]{2}{*}{ Group } & \multicolumn{2}{|c|}{ Host biometric data } & \multirow[b]{2}{*}{ TW (g) } & \multirow[b]{2}{*}{ Fulton's $K$} & \multicolumn{3}{|c|}{ - Infection parameter } & \multirow[b]{2}{*}{$\mathrm{mI}$} \\
\hline & & $\mathrm{N}$ & $\mathrm{TL}(\mathrm{cm})$ & & & $\mathrm{P}(\%)$ & $\mathrm{mA}$ & I & \\
\hline \multirow[t]{3}{*}{$M+F$} & Sample & 501 & $17.2(9.9-22.5)$ & $30.5(4.4-91.6)$ & $0.5(0.4-0.7)$ & 47.3 & $1.1(0.9 \mid 1.2)$ & $1-12$ & $2.3(2.0 \mid 2.5)$ \\
\hline & Infected & 237 & $17.5(12.1-21.3)$ & $31.5(9.4-57.8)$ & $0.5(0.4-0.7)$ & & & & \\
\hline & Uninfected & 264 & $17.0(9.9-22.5)$ & $29.1(4.4-91.6)$ & $0.5(0.4-0.7)$ & & & & \\
\hline \multirow[t]{3}{*}{ M } & Sample & 426 & $17.1(9.9-22.0)$ & $29.9(4.4-61.3)$ & $0.6(0.4-1.0)$ & 46.0 & $1.1(0.9 \mid 1.2)$ & $1-12$ & $2.4(2.1 \mid 2.7)$ \\
\hline & Infected & 196 & $17.4(12.1-21.2)$ & $31.4(9.4-57.8)$ & $0.6(0.5-0.7)$ & & & & \\
\hline & Uninfected & 230 & $16.9(9.9-22.0)$ & $28.6(4.4-61.3)$ & $0.6(0.4-1.0)$ & & & & \\
\hline \multirow[t]{3}{*}{$\mathrm{F}$} & Sample & 75 & $17.9(10.0-22.5)$ & $33.8(5.5-91.6)$ & $0.6(0.4-0.8)$ & 54.7 & $1.0(0.7 \mid 1.3)$ & $1-7$ & $1.8(1.4 \mid 2.2)$ \\
\hline & Infected & 41 & $17.9(12.6-21.3)$ & $32.5(12.2-53-3)$ & $0.5(0.4-0.7)$ & & & & \\
\hline & Uninfected & 34 & $18.3(10.0-22.5)$ & $34.9(5.5-91.6)$ & $0.6(0.4-0.8)$ & & & & \\
\hline
\end{tabular}


Möller \& Klatt (1990) found that an infection of smelt with Pseudoterranova sp. larvae reduces the overall condition and proposed an increasing susceptibility to predation. Sprengel \& Lüchtenberg (1991) demonstrated that $P$. decipiens infections of Osmerus eperlanus reduced the swimming speed of the host and enhanced the probability of transmission to its definitive host. Rohlwing et al. (1998) studied the influence of $P$. decipiens larvae on the survival rate of European smelt retained by a screen wall of a nuclear power plant. The authors stated that $P$. decipiens infections contribute to reduce the condition factor of the fish host. Fulton's condition factor $K$ is a morphometric condition index and provides a useful tool to examine the overall growth of a fish (Suthers 1998, De Raedemaecker et al. 2012). The condition factor was calculated in order to assess whether there is an influence on the fish hosts' condition during the spawning season (March). Regardless of gender, $K$ values were not significantly different in infected fish, suggesting that the host's condition may not be particularly affected during spawning. The fact that infected fish are larger than uninfected ones is not unusual and is very likely due to the longer period of time that has passed and consequently the increased probability for smelt to take up parasites within their prey. Moreover, larger individuals (ca. $6 \mathrm{~cm}$ and above) change their diet and, in addition to small crustaceans, also feed on small fishes, which favors the accumulation of nematodes (Lile 1998, Froese \& Pauly 2012). However, our results are not in accordance with this feeding behavior (Fig. 2). The intensity increased continuously up to a fish length of 17 to $19 \mathrm{~cm}$ and then decreased again. These data are similar to those of Möller \& Klatt (1990), who demon-

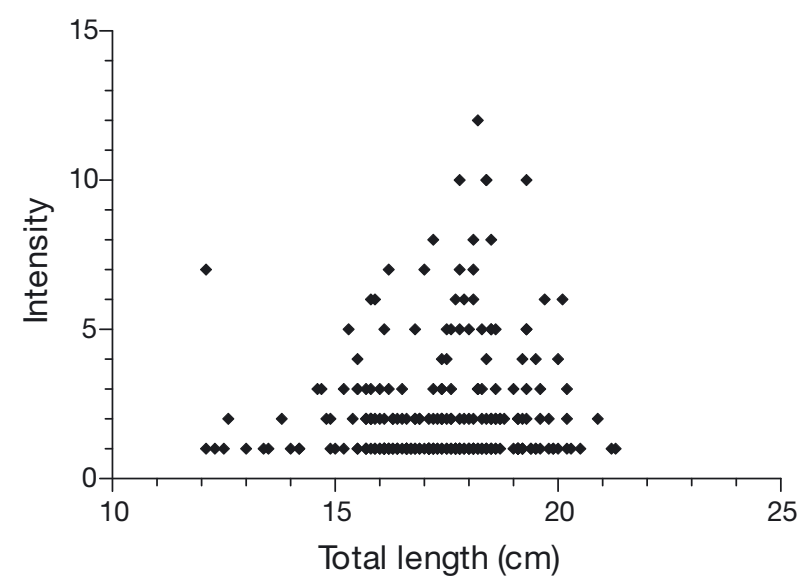

Fig. 2. Osmerus eperlanus infected with Pseudoterranova decipiens. Intensity of infection (I) in comparison to fish total length (TL) strated that the mean intensity of infection in smelt from the Elbe estuary increased in the 10 to $16 \mathrm{~cm}$ length groups and then decreased in the length groups larger than $20 \mathrm{~cm}$. We found a similar trend in our study, since there was no significant correlation between the number of nematodes and host TL (Spearman correlation $\mathrm{r}=0.07 ; \mathrm{p}<0.05$ ).

According to several authors (e.g. Rae 1963, Platt 1975, Margolis 1977, McClelland et al. 1983, Hafsteinsson \& Rizvi 1987, Landry 1990, Hauksson 2011), a notable feature of anisakid nematode infections is the increase in prevalence and intensity with increasing weight, length, and age of the fish host. Anisakid infections in the musculature and visceral organs are irreversible, and the parasites accumulate gradually over the life span of the fish host (e.g. McClelland 2002). The fact that nematode intensity does not peak in the largest fish seems to be a regular phenomenon in smelt from German waters. Brattey (1988) pointed out that candling or candling and slicing techniques to recover nematodes from the host's musculature do not always give the most accurate results, and according to McClelland et al. (1983), parasites are more difficult to detect in larger fillets. However, this circumstance is not an appropriate explanation for this phenomenon, because smelt are comparatively small fish, and the entire population of nematodes, even in the largest fillets, is relatively easy to recover. A possible explanation would be that the parasites may eventually be eliminated as a consequence of a host reaction, but even in this case, the nematodes would be more numerous in larger smelt as the frequency of reinfections would increase with the dietary uptake of the host (McClelland et al. 1983). Another possible explanation could be the possible migration of nematodes post mortem. Karl (2006) and Kahl (1936) demonstrated an intensified migration of nematodes to the surface after death of the fish host. According to the results of Sprengel \& Lüchtenberg (1991), larger fish with higher infection levels may be eliminated through higher predation pressure, resulting in decreasing infection levels among larger fish.

Möller \& Klatt (1990) studied the sites of nematode infection in a sample of 2341 European smelt and found $70 \%$ of all detected nematodes $(n=581)$ occurring in the dorsal muscle parts, whereas $26 \%$ were found in the caudal part and only $4 \%$ in the belly flaps. The vast majority of nematodes in our study was found in the musculature of Osmerus eperlanus $(\mathrm{n}=539)$. Among the muscular sections, the larvae were not equally distributed. Fig. 1 gives the number and percentage of the Pseudoterranova larvae in 
each partitioned muscular compartment (including left and right fish side). The comparison between left and right fish side revealed no major differences among the compartments. The occurrence of larvae in the head region is unusual but is presumably attributable to post mortem migration of the larvae.

Genetic identification of a subsample of nematodes from European smelt was performed on 105 individual Pseudoterranova larvae. The sequence data (GenBank accession numbers JX138238 to JX138342) were all identical (99.0\%, e-value: 0.00$)$ to a sequence from the sibling species $P$. decipiens s.s. isolated from the gadoid Gadus morhua from Danish waters (GenBank accession number JQ673268.1), suggesting that the nematodes in this study belong to the same species.

Pseudoterranova decipiens s.s. is part of the sibling-complex $P$. decipiens (see above) and is known to be the most common sibling species in Arctic and sub-Arctic regions (Mattiucci \& Nascetti 2008). In North Atlantic waters (including Iceland and Norway), it co-occurs with its congener $P$. krabbei. It is primarily a parasite of harbor seals, but it also infects grey seals in areas where $P$. krabbei is not present (Paggi et al. 1991, 2000). While in Canadian waters P. decipiens (s.l.) infestations in smelt have been reported by several authors (e.g. Scott 1954, Templeman et al. 1957, Fréchet et al. 1983, Landry 1990, Landry \& Hare 1990), information on infection levels of European smelt from German coastal waters is comparatively scarce. Especially in areas where seals do occur, such fish species often appear to carry fairly heavy burdens of P. decipiens (Möller \& Klatt 1990, Jensen \& Anderson 1992). Whether fish species are infected depends on various factors, including (1) their affinity to nenitic areas, (2) their feeding habits, and (3) the occurrence of the first intermediate (invertebrate) and especially the final (seal) host of the parasite. Rokicki (1975) demonstrated that along the Gdańsk Bay in the Baltic Sea, where seals are very rare, smelt are usually not infected with $P$. decipiens. The presence of seals in the vicinity is presumably the crucial factor. Osmerus eperlanus and Phoca vitulina are both confined to coastal waters and often co-occur in estuarine and intertidal waters near sandbars and beaches where the seals have their whelping and resting places (Jefferson et al. 2008, Froese \& Pauly 2012). Smelt feed to a large extent on bentho-pelagic invertebrates in addition to small fish (including other smelt), whereas the seals feed on a wide range of fish, cephalopods, and crustaceans obtained from surface, mid-waters, and benthic habitats (Jefferson et al. 2008, Froese \& Pauly 2012).
Phoca vitulina is the most common pinniped species in the German Wadden Sea, followed by Halichoerus grypus (Vossen et al. 2004). Both are known to be infected with Pseudoterranova decipiens (Lick 1991, Bristow \& Berland 1992). Whilst several publications have demonstrated that in the North Sea smelt (among other piscivorous fishes) are a typical part of the diet of $P$. vitulina, it can be assumed that smelt act as important link in the life cycle of P. decipiens s.s.

The assessment of the occurrence of Pseudoterranova decipiens s.s. in the musculature of the European smelt is essential in light of the importance of this fish as a regional food specialty. Although the infection with sealworms (pseudoterranovosis) cannot be considered a major public health problem in German coastal waters, the presence of nematodes in fish is nevertheless repugnant to the average consumer (McClelland et al. 1983, Hafsteinsson \& Rizvi 1987). This is a chronic cosmetic problem, and wide sections of the local population are probably aware of it; however, with proper preparation of the fish, restaurants can avoid certain cosmetic disadvantages.

Acknowledgements. We thank H. Kappes for technical assistance and gratefully acknowledge H.W. Palm and the anonymous reviewers for their useful comments. This study was financially supported by the research funding program 'LOEWE-Landes-Offensive zur Entwicklung Wissenschaftlich-ökonomischer Exzellenz' of Hesse's Ministry of Higher Education, Research, and the Arts.

\section{LITERATURE CITED}

Altschul SF, Gish W, Myers WMEW, Lipmann DJ (1990) Basic local alignment search tool. J Mol Biol 215:403-410 Anderson RC (2000) Nematode parasites of vertebrates. Their development and transmission. CABI International, Wallingford

Audicana MT, Kennedy MW (2008) Anisakis simplex: from obscure infectious worm to inducer of immune hypersensitivity. Clin Microbiol Rev 21:360-379

> Brattey J (1988) A simple technique for recovering larval ascaridoid nematodes from the flesh of marine fish. J Parasitol 74:735-737

$>$ Bristow GA, Berland B (1992) On the ecology and distribution of Pseudoterranova decipiens C (Nematoda: Anisakidae) in an intermediate host, Hippoglossoides plattessoides, in northern Norwegian waters. Int J Parasitol 22:203-208

Bush AO, Lafferty KD, Lotz JM, Shostak AW (1997) Parasitology meets ecology on its own terms: Margolis et al. revisited. J Parasitol 83: 575-583

> De Raedemaecker F, Brophy D, O'Connor I, O'Neill B (2012) Dependence of RNA:DNA ratios and Fulton's K condition indices on environmental characteristics of plaice and dab nursery grounds. Estuar Coast Shelf Sci 98: $60-70$ 
Fréchet A, Dodson JJ, Powles H (1983) Les parasites de l'Éperlan d'Amerique (Osmerus mordax) anadrome du Québec et leur utilité comme etiquettes biologiques. Can J Zool 61:621-626

Froese R, Pauly D (eds) (2012) FishBase. www.fishbase.org

Hafsteinsson H, Rizvi SSH (1987) A review of the sealworm problem: biology, implications and solutions. J Food Prot 50:70-84

Hauksson E (2011) The prevalence, abundance, and density of Pseudoterranova sp. (p) larvae in the flesh of cod (Gadus morhua) relative to proximity of grey seal (Halichoerus grypus) colonies on the coast off Drangar, northwest Iceland. J Mar Biol 2011:235832

Ivanova NV, deWaard J, Hebert PDN (2006) An inexpensive, automation-friendly protocol for recording highquality DNA. Mol Ecol Notes 6:998-1002

Jefferson TA, Webber MA, Pitman RL (2008) Marine mammals of the world: a comprehensive guide to their identification. Elsevier, Amsterdam

> Jensen T, Anderson K (1992) The importance of sculpin (Myoxocephalus scorpius) as intermediate host and transmitter of the sealworm Pseudoterranova decipiens. Int J Parasitol 22:665-668

Kahl W (1936) Über den Befall des Stints mit Larven des Fadenwurms Porrocaecum decipiens. Fischmarkt 7:177-181

Karl H (2006) Composition and nematodes in smelt (Osmerus eperlanus L.). Inf Fischereiforsch 53:65-70

Klimpel S, Palm HW (2011) Anisakid nematode (Ascaridoidea) life cycles and distribution: increasing zoonotic potential in the time of climate change? In: Mehlhorn $\mathrm{H}$ (ed) Progress in parasitology. Parasitology Research Monographs 2. Springer-Verlag, Heidelberg, p 201-222

> Køie M, Berland B, Burt MDB (1995) Development to thirdstage larvae occurs in the eggs of Anisakis simplex and Pseudoterranova decipiens (Nematoda, Ascaridoidea, Anisakidae). Can J Fish Aquat Sci 52:134-139

Kovpak NE, Skurikhina LA, Kukhlevsky AD, Oleinik AG, Sendek DS (2011) Genetic divergence and relationship among smelts of the genus Osmerus from Russian waters. Russ J Genet 47:958-972

Kuhn T, García-Màrquez J, Klimpel S (2011) Adaptive radiation within marine anisakid nematodes: a zoogeographical modeling of cosmopolitan, zoonotic parasites. PLoS ONE 6:e28642

Landry T (1990) Annual and geographical variations in sealworm (Pseudoterranova decipiens) larvae in rainbow smelt (Osmerus mordax) from the Gulf of St. Lawrence. Can Tech Rep Fish Aquat Sci 1734:1-11

Landry T, Hare GM (1990) Abundance of sealworm (Pseudoterranova decipiens) in rainbow smelt (Osmerus mordax) from the southwestern Gulf of St. Lawrence. Can Bull Fish Aquat Sci 222:119-227

Lick R (1991) Untersuchungen zu Lebenszyklus (KrebseFische-marine Säuger) und Gefrierresistenz anisakider Nematoden in Nord- und Ostsee. Ber Inst Meereskd Christian-Albrechts-Univ Kiel 218:1-195

Lile NK (1998) Alimentary tract helminths of four pleuronectid flatfish in relation to host phylogeny and ecology. J Fish Biol 53:945-953

> Margolis L (1977) Public health aspects of 'codworm' infections: a review. J Fish Res Board Can 34:887-898

Mattiucci S, Nascetti G (2008) Advances and trends in the molecular systematics of anisakid nematodes, with implications for their evolutionary ecology and host-parasite co-evolutionary processes. Adv Parasitol 66:47-148
Mattiucci S, Paoletti M, Damiano S, Nascetti G (2007) Molecular detection of sibling species in anisakid nematodes. Parassitologia (Rome) 49:147-153

McClelland G (2002) The trouble with sealworms (Pseudoterranova decipiens species complex, Nematoda): a review. Parasitology 124:183-203

McClelland G (2005) Nematoda (roundworms). In: Rohde K (ed) Marine parasitology. CABI Publishing, Wallingford, p 104-116

McClelland G, Misra RK, Marcogliese DJ (1983) Variations in abundance of larval anisakines, sealworm (Phocanema decipiens) and related species in cod and flatfish from the Southern Gulf of St. Lawrence (4T) and the Breton Shelf (4Vn). Can Tech Rep Fish Aquat Sci 1201: $1-51$

Möller H, Klatt S (1990) Smelt as host of the sealworm (Pseudoterranova decipiens) in the Elbe estuary. Can Bull Fish Aquat Sci 222:129-138

Nadler SA, D'Amelio S, Dailey MD, Paggi L, Siu S, Sakanari JA (2005) Molecular phylogenetics and diagnosis of Anisakis, Pseudoterranova, and Contracaecum from northern Pacific marine mammals. J Parasitol 91:1413-1429

> Obiekezie AI, Lick R, Kerstan S, Möller H (1992) Larval nematodes in stomach wall granulomas of smelt Osmerus eperlanus from the German North Sea coast. Dis Aquat Org 12:177-183

> Paggi L, Nascetti G, Cianchi R, Orecchia P and others (1991) Genetic evidence for three species within Pseudoterranova decipiens (Nematoda, Ascaridida, Ascaridoidea) in the North Atlantic and Norwegian and Barents Sea. Int J Parasitol 21:195-212

Paggi L, Mattiucci S, Gibson DI, Berland B, Nascetti G, Cianchi R, Bullini L (2000) Pseudoterranova decipiens species A and B (Nematoda, Ascaridoidea): nomenclatural designation, morphological diagnostic characters and genetic markers. Syst Parasitol 45:185-197

Platt NE (1975) Infestation of cod (Gadus morhua L.) with larvae of codworm (Terranova decipiens Krabbe) and herringworm, Anisakis sp. (Nematoda Ascaridata), in North Atlantic and Arctic waters. J Appl Ecol 12: $437-450$

Quiazon KM, Yoshinaga T, Santos MD, Ogawa K (2009) Identification of larval Anisakis spp. (Nematoda: Anisakidae) in Alaska pollock (Theragra chalcogramma) in northern Japan using morphological and molecular markers. J Parasitol 95:1227-1232

Rae BB (1963) The incidence of larvae of Porrocaecum decipiens in the flesh of cod. Mar Res 2:1-28

Reise K, Baptist M, Burbridge P, Dankers N and others (2010) The Wadden Sea - a universally outstanding tidal wetland. Wadden Sea Ecosystem No. 29. Common Wadden Sea Secretariat, Wilhelmshaven

Ricker WE (1975) Computation and interpretation of biological statistics of fish populations. Bull Fish Res Board Can 191:1-382

> Rohlwing T, Palm HW, Rosenthal H (1998) Parasitation with Pseudoterranova decipiens (Nematoda) influences the survival rate of the European smelt Osmerus eperlanus retained by a screen wall of a nuclear plant. Dis Aquat Org 32:233-236

Rokicki J (1975) Helminth fauna of fishes of the Gdańsk Bay (Baltic Sea). Acta Parasitol Pol 23:37-84

Scott DM (1954) Experimental infection of Atlantic cod with a larval marine nematode from smelt. J Fish Res Board Can 11:894-900 
Sprengel G, Lüchtenberg H (1991) Infection by endoparasites reduces maximum swimming speed of European smelt Osmerus eperlanus and European eel Anguilla anguilla. Dis Aquat Org 11:31-35

Suthers IM (1998) Bigger? Fatter? Or is fast growth better? Conclusions on condition in larval and juvenile coral-reef fish. Aust J Ecol 23:265-273

Templeman WH, Squires HJ, Fleming AM (1957) Nematodes in the fillets of cod and other fishes in the Newfoundland and neighbouring areas. J Fish Res Board Can 14:831-897

TSEG (Trilateral Seal Expert Group) (2011) Aerial surveys of harbour seals in the Wadden Sea in 2010: strong increase in pups, slight increase in total number? TSEG, Common Wadden Sea Secretariat, Wilhelmshaven

Vossen A, Abdulmawjood A, Lämmler C, Weiß R, Siebert U (2004) Identification and molecular characterization of beta-hemolytic streptococci isolated from harbour seals (Phoca vitulina) and grey seals (Halichoerus grypus) of

Editorial responsibility: Bernd Sures,

Essen, Germany the German North and Baltic Seas. J Clin Microbiol 42: 469-473

Wolff WJ, Bakker JP, Laursen K, Reise K (2010) The Wadden Sea Quality Status Report - Synthesis Report 2010. Wadden Sea Ecosystem No. 29. Common Wadden Sea Secretariat, Wilhelmshaven

> Yu JR, Seo M, Kim YW, Oh MH, Sohn WM (2001) A human case of gastric infection by Pseudoterranova decipiens larva. Korean J Parasitol 39:193-196

Zhu XQ, Gasser RB, Jacobs DE, Hung GC, Chilton NB (2000) Relationships among some ascaridoid nematodes based on ribosomal DNA sequence data. Parasitol Res 86:738-744

Zhu XQ, D'Amelio SD, Palm HW, Paggi L, George-Nascimento M, Gasser RB (2002) SSCP-based identification of members within the Pseudoterranova decipiens complex (Nematoda: Ascaridoidea: Anisakidae) using genetic markers in the internal transcribed spacers of ribosomal DNA. Parasitology 124:615-623

Submitted: June 11, 2012; Accepted: November 2, 2012

Proofs received from author(s): January 23, 2013 